\title{
Conceptualizing Post-COVID-19 Malaysia's Tourism Recovery: An Auto-Regressive Neural Network Analysis
}

\author{
Anantha Raj A. Arokiasamy ${ }^{1 *}$, Philip Michael Ross Smith ${ }^{1}$, Thanapat Kijbumrung ${ }^{1}$ \\ ${ }^{I}$ School of Business and Management, RMIT International University, Ho Chi Minh City, Vietnam
}

\begin{abstract}
The pandemic caused by the SARS-CoV-2 virus (COVID-19) has significantly affected the tourism industry. Tourist destinations have adopted emergency measures and restrictions that have affected the mobility of individuals around the world. This study aims to analyze the effects of the COVID-19 pandemic on the tourism industry in Malaysia and its overall economic performance. This research used an extensive set of statistical tests, including a newly constructed AutoRegressive Neural Network-ADF (ARNN-ADF) test, to determine if foreign visitor arrivals from 10 main source markets in Malaysia will revert to normal. Secondary data from various government published sources were used in this conceptual methodology technique for this study. Based on the research results and exploratory research of the literature, we listed in a synthesizing manner several measures to ensure the resilience of the tourism sector during the COVID-19 pandemic period. This research makes a significant contribution to the literature in terms of validating a new framework that emphasizes the effects of tourists that are largely transitory. In conclusion, this conceptual study will further help the authorities to take precautions and the best policy to be implemented in the future.
\end{abstract}

\section{Keywords:}

COVID-19 Pandemic;

Tourism; Hospitality;

Non-linearity;

Auto-Regressive Neural Network;

Unit Root.

\section{Article History:}

Received: $\quad 08$ June 2021

Revised: $\quad 14 \quad$ August 2021

Accepted: 23 August 2021

Published: $06 \quad$ September 2021

\section{1- Introduction}

Thanks to the tourist and hospitality industries, countries with wonderful vacation destinations gain considerably from the economic growth generated by tourism and hospitality; consequently, the service sectors also reduce unemployment in such countries. Because tourist vacations cover domestic and foreign visits, the hospitality industry needs numerous modes of transportation such as air travel, railway travel, cruise ship travel, and public transportation services. The industry must also supply various food and beverage (F\&B) cuisines through multiple outlets serving specialty and luxury menus or basic foods. Lodging, too, is critical to a tourist's enjoyment, embracing hotels, motels, guest houses, guest rooms, homestays, and hostels from 1 to 5 stars. Moreover, holiday outlets deliver entertainment through destination spots like cinemas, shopping malls, beaches, museums, amusement and theme parks, restaurants, forests, and rural tourism spots. As mentioned, tourists and the hotel industry have a significant impact on GDP and the economy of all countries likewise, they are major contributors to the growth of the Malaysian economy [1].

Malaysia's economy has been severely impacted by the emergence of COVID-19, most notably the travel and tourism industry. This year, the Malaysian government is estimated to have lost Malaysian Ringgit (RM) 3.37 billion [2]. Tour and vacation packages have been cancelled, which causes serious trouble for hotels and airlines in the vicinity [3]. Malaysia's most famous tourist sites have seen an unprecedented drop in the number of international travelers. Malaysian government estimates indicate that the country's Gross Domestic Product (GDP) has fallen by between 0.8 percent and 1.2 percent during the last year (RM10.8 billion to RM17.3 billion).

* CONTACT: anantharaj.arokiasamy@rmit.edu.vn

DOI: http://dx.doi.org/10.28991/esj-2021-SPER-10

(C) 2021 by the authors. Licensee ESJ, Italy. This is an open access article under the terms and conditions of the Creative Commons Attribution (CC-BY) license (https://creativecommons.org/licenses/by/4.0/). 
Malaysia is in the southern-eastern hemisphere and consist of thirteen states and three federal territories, all of which have different cultural perspectives. Numerous minorities, notably Bumiputras, Chinese, and Indians, live in Malaysia, a multi-cultural and multi-ethnic country with many ethnic groups [4]. Post-independence GDP in Malaysia has grown at an average rate of 6.5 percent per year due to the wealth of natural resources and contributions provided by the tourist and hospitality industry and other industries like science, technology, information technology, commerce, and medical tourism. Malaysia is a beautiful country with stunning tourist destinations such as beaches, landscapes, islands, hill stations, mountains, World Heritage Sites, national parks and nature reserves, and rural tourism. It is a popular tourist destination with visitors worldwide, resulting in increased tourism and economic benefits for the country's tourism and hospitality industries [5].

Against this backdrop, this study investigates whether international tourist arrivals in Malaysia will recover to precrisis levels by looking at the mean-reverting tendency of arrivals from Malaysia's key source markets. If the arrivals are proven to be mean-reverting, they will recover to normal levels following shocks like the present COVID-19 pandemic. If, on the other hand, tourist arrivals do not imply reversion, the number of arrivals will not return to normal. As a result, relevant policy measures are necessary. Given the substantial economic contribution to Malaysia, the goal of this research is to determine how the COVID-19 outbreak has affected the Malaysian tourism industry. We will assess if the reduction in inbound visitors to Malaysia caused by the pandemic has been permanent or just transitory due to the first shock from the COVID-19 pandemic. The auto-regressive neural network-ADF (ARNN-ADF) test, which was recently created, is used in this research [6]. This is one of few studies used to evaluate foreign visitor arrivals using the ARNN-ADF test. This test has a methodological benefit in that it includes a hidden layer that captures the latent structure of time series data.

In this paper, we aim to investigate the effects of the COVID-19 crisis on the tourism industry and overall economic performance. We synthesize, in addition, the measures that tourism operators can take to cope with the sharp decline in activity and consumers of tourism services and the opportunity for sustainable tourism offered by the COVID-19 pandemic. The paper also highlights the substantial role of the tourism industry in economic development, given that tourism is the economic sector most affected by the COVID-19 pandemic. The structure of the paper is composed of five sections. After the introduction and literature review, we described the research design. The succeeding three sections show the results, the discussions, and specific measures for the tourism industry.

\section{2- Materials and Methods}

The research design of this study comprises five steps, as follows: (1) Literature Review; (2) Method Application; (3) Results and Analysis; (4) Discussion; and (5) Conclusion (see Figure 1).

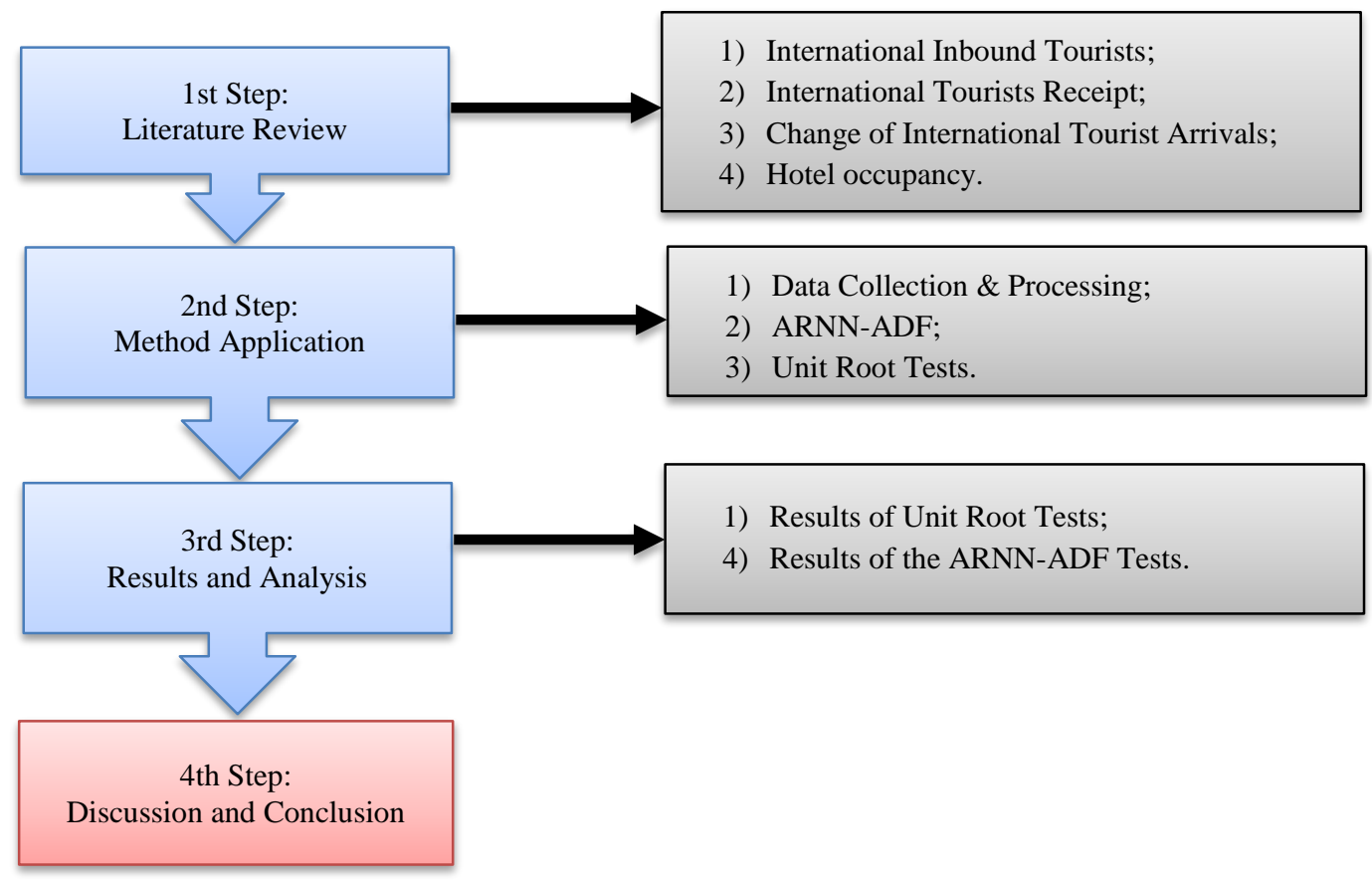

\section{2-1- Economic Impact of Tourism}

Figure 1. Flowchart of Research Design

Tourism and hospitality have taken an enormous hit because of the COVID-19 sickness and the widespread nature of the disease. Currently, the COVID-19 pandemic has had an unprecedented negative economic impact on numerous 
industries, including tourism, which is suffering primarily because of international travel restrictions imposed in many parts of the world. In the short and possibly long term, the pandemic will decrease international visitors to tourist destinations. It is projected that the number of foreign arrivals would decline by nearly 20-30 percent, resulting in revenue losses in the worldwide tourist industry of between USD300 and 450 billion. In 2020, a reduction in the number of foreign passengers resulted in revenue losses for airlines of roughly USD252 billion and revenue losses for airports of approximately USD77 billion [7]. Millions of livelihoods and jobs have been eliminated because of travel restrictions and border closures in virtually every country across the world [8].

The Malaysian Institute of Economic Research's (MIER) projection of 4 percent GDP growth was reduced to just 2.9 percent in 2020, resulting in employment losses of up to 2.4 million, with 67 percent of those losses occurring in the unskilled group. Initial estimates from the International Labor Organization (ILO) indicate that unemployment and underemployment are growing substantially as the crisis worsens [9] (Garcia-Muñoz Alhambra et al., 2020). According to external sources, it is anticipated that the unemployment rate and real GDP growth in Malaysia would decline in both the baseline and in several scenarios [10]. According to the report, Malaysia's GDP will expand faster than the rest of the world's economy in the near future (Figure 2). COVID-19's effects on the Visit Malaysia 2020 campaign in Malaysia have been frightening. As 64 percent of the tourism business in Malaysia originated from China, Singapore, or Indonesia, which were all badly affected by the pandemic, Malaysia's tourism industry was seriously damaged [11]. In the first six months of 2020, Movement Control Orders (MCO's) economic impacts on the country have resulted in an estimate of about RM45 billions of losses from the tourism sector according to the Ministry of Tourist, Arts and Culture (MOTAC) [12]. The leading tourist sectors are transport, accommodation, restaurant sector, and event business (Figure 3). Until recently, tourism was one of the most significant economy-boosting sectors in Malaysia. The tourism sector also experienced incredible growth worldwide. Tourism generates income through tourist spending at a rapid pace. Tourists spend on travel expenses, lodging services expenses, hotel-staying expenses, food expenses, and other tourist destination-related expenses. In the tourism and hospitality business, there are about 197 million extra employment hazards alone, with a projected 5.5 billion losses in travel and tourism of GDP this year as a result of long-standing travel constraints and MCO's imposed by the countries [12].

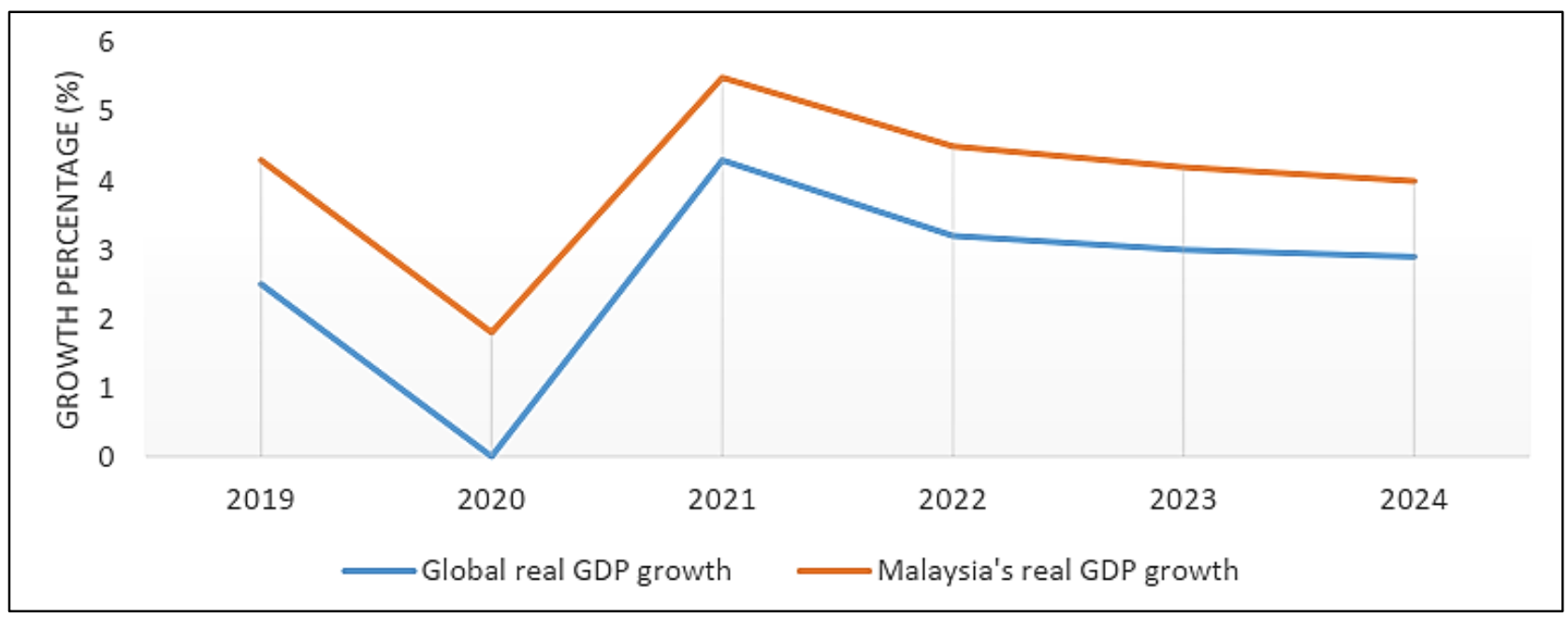

Figure 2. Economic Growth in Malaysia.

\section{2-2- International Inbound Tourists}

Malaysia welcomed a record of 13.35 million international tourists during the first six months of 2019, resulting in an increase in tourism income of 6.8 percent, which contributed to the nation's coffers by RM41.69 billion. In a recent study, the average stay time of tourists has grown by 0.4 to 6.2 days, according to Tourism Malaysia [12]. It states that Singapore, Indonesia, China, Brunei, India, South Korea, the Philippines, Japan and Australia were the top 10 foreign tourist arrivals. In the last two decades the number of overseas visitors to ASEAN countries has shown a constant increase (1995-2019). Singapore, Indonesia, Vietnam, and the Philippines are the top five tourist destinations in the world for international visitors. Thailand and Malaysia are the top two destinations for international tourists. Thailand and Malaysian tourism received 38.18 and 25.83 million international visitors, respectively, in 2019 [13]. According to Table 1, Malaysia receives the highest number of international tourists. It was Singapore that received the largest share of inbound visitors (47.74\%), followed by Indonesia (11.18\%), while Australia received the smallest amount of inbound visitors $(1.70 \%)$. 


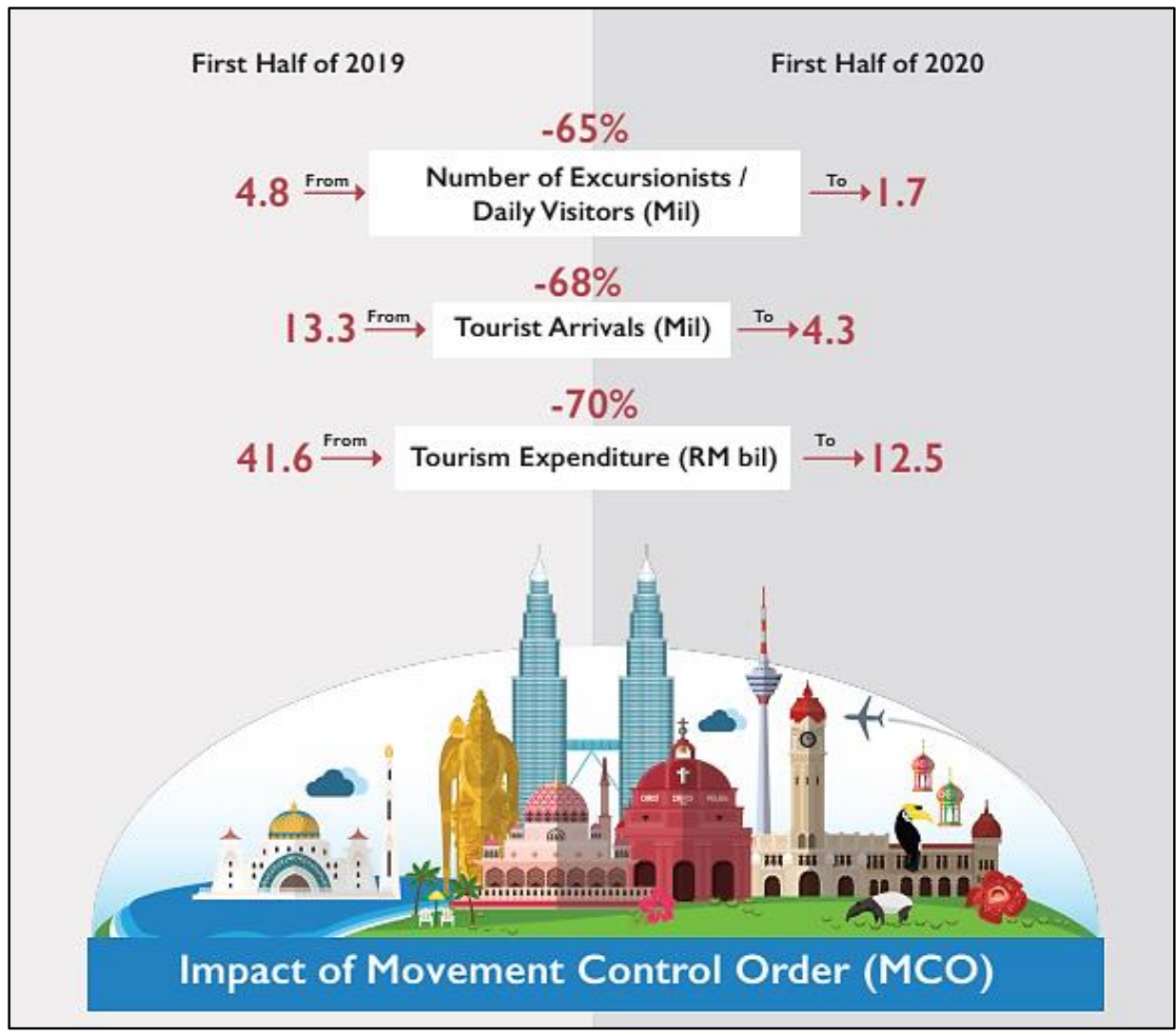

Figure 3. Impact of MCO on the Tourism Sector.

Table 1. International Tourist Arrivals in Malaysia.

\begin{tabular}{cccc}
\hline No. & Nationality & Tourist & Percentage (\%) \\
\hline 1. & Singapore & $99,551,305$ & 47.74 \\
2. & Indonesia & $23,306,535$ & 11.18 \\
3. & China & $17,130,257$ & 8.21 \\
4. & Thailand & $12,478,663$ & 5.98 \\
5. & Brunei & $10,493,282$ & 5.03 \\
6. & India & $5,361,446$ & 2.57 \\
7. & Philippines & $3,845,321$ & 1.84 \\
8. & Japan & $3,645,538$ & 1.75 \\
9. & South Korea & $3,584,344$ & 1.72 \\
10. & Australia & $3,541,296$ & 1.70 \\
\hline & Top-10 Total & $182,937,987$ & 87.72 \\
& ROW* Total & $25,607,736$ & 12.28 \\
\hline & Global Total & $208,545,723$ & 100.00 \\
\hline
\end{tabular}

Note: *ROW stands for the rest of the world.

Table 2. International Tourist Receipts for Malaysia, 2014-2019.

\begin{tabular}{lccccccc}
\hline Country & Unit & $\mathbf{2 0 1 4}$ & $\mathbf{2 0 1 5}$ & $\mathbf{2 0 1 6}$ & $\mathbf{2 0 1 7}$ & $\mathbf{2 0 1 8}$ & $\mathbf{2 0 1 9}$ \\
\hline \multirow{2}{*}{ Malaysia } & Billion (USD) & 24.47 & 19.19 & 19.68 & 20.31 & 21.77 & 22.38 \\
& \% of total exports & 9.81 & 9.16 & 9.79 & 9.08 & 8.83 & 8.76 \\
\hline
\end{tabular}

\section{2-3- Impact of COVID-19 on International Tourists Arrivals}

In its 2020 report, the Adventure Travel Trade Association (ATTA) stated that firms and organizations throughout the tourism sector are struggling and are not immune to the current economic climate. In the face of COVID-19 related 
social limitations, even the most fundamental duties required by the company to generate money are impossible, which cause financial issues with the passage of each day when mobility and travel limits are implemented [16]. Revenues have fallen significantly, but expenses continue to accumulate. Cash flow has become a significant issue for the sector. Almost a year after the first confirmed cases of COVID-19 were discovered in the Chinese city of Wuhan, the pandemic has caused extraordinary disruptions to foreign visitor arrivals in several countries across Southeast Asia [17]. Table 3 shows the foreign arrivals of the main tourist groups in Malaysia before and after closing the borders. As demonstrated in Table 3, the number of international tourists arriving in Malaysia has fallen considerably since the onset of COVID19. In large part, this is due to tourists' concerns about their health risks and the actions of their respective governments about travel restrictions. When comparing the number of inbound visitors from February 2019 to February 2020, many international tourists' arrivals in Malaysia have decreased significantly, particularly those from Brunei and South Korea, which have decreased from -55.15 to -52.34 percentage points, respectively. In February 2020, only visitor arrivals from India had a 15.63 percent rise over the previous month.

Table 3. Changes of International Tourist Arrivals in Feb. 2019 versus Feb. 2020.

\begin{tabular}{cccc}
\hline Nationality & Feb. 2019 & Feb. 2020 & $\Delta(\boldsymbol{\%})$ \\
\hline Singapore & 813,186 & 494,638 & -39.17 \\
Indonesia & 297,666 & 256,212 & -13.93 \\
China & 295,150 & 70,137 & -76.24 \\
Thailand & 162,595 & 126,191 & -22.39 \\
Brunei & 102,571 & 45,998 & -55.15 \\
India & 51,447 & 59,488 & 15.63 \\
Philippines & 30,512 & 22,474 & -26.34 \\
Japan & 34,750 & 32,963 & -5.14 \\
South Korea & 64,366 & 30,679 & -52.34 \\
Australia & 24,602 & 19,330 & -21.43 \\
\hline
\end{tabular}

COVID-19's effects on the Visit Malaysia 2020 campaign in Malaysia have been frightening. As 64 percent of the tourism business in Malaysia originated from China, Singapore, or Indonesia, which were all badly affected by the pandemic, Malaysia's tourism industry was seriously damaged [18]. From January to March 2020, the Tourist, the Arts and Culture Ministry of Malaysia (MOTAC) predicts losses of RM9 billion for the country's major tourism operators comprising the transport, accommodation, restaurant sector, and event business [19]. According to hotel cancellation statistics, about 170,085 rooms were cancelled, resulting in an income decline of RM68 million by the 16th of March 2020 [20]. The study claims that around 17 percent of hotel employees have reported a greater level of sadness due to having to take an unpaid vacation, have their pay decreased, or be permanently laid off. During the first phase of the MCO, lasting from the 18th of March 2020 to the 31st of March 2020, the hotel business lost RM510 million in room income. Throughout the MCO's second phase, losses are projected to increase to a total of RM570 million [21]. The projected revenue loss in the hotel sector for the first half of 2020 is about RM3.3 billion compared to the same time in 2019, claims the CEO of the Malaysian Association of Hotels [21]. If this hypothesis is correct, the predicted current year occupancy rate will be about 30 percent [22]. Unfortunately, when the occupancy rate is below 50 percent, the hotel is not anticipated to make a profit. According to this estimate, roughly 30 percent of the hotel players in Malaysia will close their doors permanently or temporarily if the pandemic scenario worsens further [23].

Table 4. Malaysia's Hotel Occupancy Comparison for 2019 vs. 2020.

\begin{tabular}{ccccc}
\hline Comparison & $\mathbf{2 0 1 9}$ & $\mathbf{2 0 2 0}$ & Average Daily Rate (RM) & Estimated Loss of Room Revenue (RM) \\
\hline Month & Occupancy $(\%)$ & Occupancy $(\%)$ & & Based on 200,000 Star Rated Hotel Rooms Only \\
\hline January & 58.5 & 55 & 227.89 & $(49,452,130)$ \\
February & 67.72 & 44 & 238.07 & $(327,527,183)$ \\
March & 64.99 & 22 & 223.64 & $(596,085,583)$ \\
April & 64.68 & 6 & 219.55 & $(1,126,568,133)$ \\
May & 52.91 & 11 & 206.70 & $(537,093,414)$ \\
June & 64.10 & 16 & 228.75 & $(660,172,500)$ \\
\hline Total Amount $(\mathbf{R M})$ & & & $\mathbf{( 3 , 2 9 6 , 8 9 8 , 9 4 3 )}$ \\
\hline
\end{tabular}

Source: This table is based on a survey conducted by MAH, published on The Edge Malaysia Weekly on the 27th of April 2020 


\section{3- Results and Discussion}

Malaysia's incoming visits to the country have declined owing to the stresses from the COVID-19 pandemic, but we still need to do unit root testing to confirm if this is permanent or temporary. If we treat the time series as consisting of stationary processes, then we may infer that the impacts of shocks on visitor arrivals are transient (or if the unit root null hypothesis is not rejected). Shock-induced changes in visitors may be regarded to be long-term if they are considered non-stationary processes (or if the null hypothesis for the unit root is not rejected). The series can be classified as stationary or non-stationary based on a variety of approaches. Other test types mentioned above are also called Augmented Dickey and Fuller [24], Phillips and Perron [25], and Kwiatkowski et al. [26].

Specifically, the data examined in this study pertains to incoming tourists to Malaysia from the top ten origin countries (Singapore, Indonesia, China, Thailand, Brunei, India, Philippines, Japan, South Korea \& Australia). The data used for the analysis are monthly data sets obtained from the Malaysia Tourism Promotion Board, from the year $2012-$ 2020. The availability of data determined how long the sample span used for the empirical study [27], and the number of observations was 512. The ARNN-ADF test was used to determine if foreign tourist arrivals were a mean-reverting phenomenon. The ADF test is enhanced with a novel multilayer perceptron architecture in this nonlinear unit root test. The multilayer perception framework (one input layer, one hidden layer, and one output layer) is defined as follows [6]:

$x_{t}=\sum_{j=1}^{q} \beta_{j} \psi\left(\gamma_{j} w_{t}\right)$

where $x_{t}$ is the output, $w_{t}=\left(y_{t}-{ }_{1}, y_{t}-{ }_{2}, \ldots y_{t}-{ }_{k}\right)$ ' is the $k \times 1$ vector of inputs, $\mathrm{k}$ is the number of inputs, $\gamma_{j}=\left(\gamma_{1 \mathrm{j}}, \gamma_{2 \mathrm{j}}\right.$, $\ldots \ldots . \gamma_{\mathrm{kj}}$, ' is the $k \times 1$ vector of weights of $j^{\text {th }}$ hidden unit, $q$ is the number of hidden units, is the hidden unit, $\psi(\gamma j w t) \beta$ is the connector strength parameter that measures the strength of the connection between inputs and outputs. The activation function could be expressed as a logistic function. Using the Maclaurin series (i.e. the third-order Taylor series $w 0=0$ ), expansion function on the logistic function could be expressed as [6]:

$\psi\left(\gamma_{j} w_{t}\right)=k_{0}+\sum_{i=1}^{p} k_{i} w_{t i}+\sum_{i=0}^{p} \sum_{l=i}^{p} k_{i l} w_{t i} w_{t l}+\sum_{i=0}^{p} \sum_{l=i}^{p} \sum_{j=l}^{p} k_{i l j} w_{t i} w_{t l} w_{t j}+v_{t}$

where $k i$ are the coefficients and $v t$ is a residual. In a first-order auto-regressive AR(1) model, inputs could be expressed as $w_{t}=\left(y_{t}-1\right)$ and $p$ is set to 1 . Subsequently, Equation 2 can be rewritten as:

$\psi\left(\gamma_{j} w_{t}\right)=k_{0}+k_{1} y_{t-1}+k_{00} y_{t}^{2}+k_{01} y_{t} y_{t-1}+k_{11} y_{t-1}^{2}+k_{000} y_{t}^{3}+k_{001} y_{t} y_{t-1}+k_{011} y_{t} y_{t-1} y_{t-1}+k_{111} y_{t-1}^{3}+v_{t}$

This activation function could be put into an ADF framework; therefore, the ARNN-ADF unit root test could be expressed as:

$$
\begin{aligned}
& (1-L) y_{t}=\alpha+\beta t+k_{0}+k_{1} y_{t-1}+k_{00} y_{t}^{2}+k_{01} y_{t} y_{t-1}+k_{11} y_{t-1}^{2}+k_{000} y_{t}^{3}+k_{001} y_{t} y_{t} y_{t-1}+ \\
& k_{011} y_{t} y_{t-1} y_{t-1}+k_{111} y_{t-1}^{3}+\sum_{k=1}^{q} \delta_{k}(1-L) y_{t-k}+\varepsilon_{t}
\end{aligned}
$$

For the ease of calculations, $\mathrm{q}$ is set to 1 in this analysis.

We use the ADF, PP and KPSS unit root tests for empirical analysis as Chen (2002) [28] and Cavaliere (2005) [29]. The early and pioneering work on testing for a unit root in time series was done by Dickey and Fuller [30]. In this case, the basic objective of the test is to test the null hypothesis that $\varphi=1 \mathrm{in}: y_{\mathrm{t}}=\varphi y_{\mathrm{t}-1}+u_{\mathrm{t}}$ against the one-sided alternative $\varphi<1$. So, we have a null hypothesis $\left(\mathrm{H}_{0}\right)$ : series contains a unit root (or the series is non-stationary) vs. alternative hypothesis $\left(\mathrm{H}_{1}\right)$ : series does not contain a unit root (or the series is stationary). We usually use the regression:

$\Delta y_{\mathrm{t}}=\psi y_{\mathrm{t}-1}+u_{\mathrm{t}}$ so that a test of $\varphi=1$ is equivalent to a test of $\psi=0($ since $\varphi-1=\psi)$.

\section{3-1- Unit Root Tests for Stationarity}

The ADF, PP, and KPSS unit root tests are used to determine if the drop in inbound visits to Malaysia because of the shocks caused by the COVID-19 pandemic is permanent or transitory. Table 5 presents the findings of the study. As found in Singapore, China, Brunei, South Korea, and Australia, the short-term impact of COVID-19 on inbound tourists consists of reductions in outbound visitors, while the long-term impact of COVID-19 on inbound tourists shows reductions in the number of outbound visitors as well as increases in the number of inbound visitors. 
Table 5. Results of Unit Root Tests.

\begin{tabular}{cccc}
\hline & \multicolumn{3}{c}{ Inbound Tourists to Malaysia } \\
\hline Nationality & ADF & PP & KPSS \\
\hline Singapore & $-0.98 \mathrm{~ns}$ & $-7.29 \mathrm{~s}$ & $0.25 \mathrm{~ns}$ \\
Indonesia & $-7.59 \mathrm{~s}$ & $-7.58 \mathrm{~s}$ & $0.08 \mathrm{~s}$ \\
China & $-1.57 \mathrm{~ns}$ & $-4.91 \mathrm{~s}$ & $0.30 \mathrm{~ns}$ \\
Thailand & $-5.90 \mathrm{~s}$ & $-5.99 \mathrm{~s}$ & $0.16 \mathrm{~ns}$ \\
Brunei & $-2.47 \mathrm{~ns}$ & $-8.45 \mathrm{~s}$ & $0.13 \mathrm{~s}$ \\
India & $-0.70 \mathrm{~ns}$ & $-6.03 \mathrm{~s}$ & $0.18 \mathrm{~ns}$ \\
Philippines & $-4.72 \mathrm{~s}$ & $-4.90 \mathrm{~s}$ & $0.18 \mathrm{~ns}$ \\
Japan & $-6.22 \mathrm{~s}$ & $-6.20 \mathrm{~s}$ & $0.16 \mathrm{~ns}$ \\
South Korea & $-1.14 \mathrm{~ns}$ & $-5.58 \mathrm{~s}$ & $0.10 \mathrm{~s}$ \\
Australia & $-0.89 \mathrm{~ns}$ & $-8.65 \mathrm{~s}$ & $0.14 \mathrm{~s}$ \\
\hline
\end{tabular}

Notes: (1). ADF, PP and KPSS are the test statistics for the Dickey and Fuller (1979), and the Phillips and Perron (1988) unit-root tests, and the Kwiatkowski et al. (1992) stationarity test, respectively. (2). $s=$ stationary, $n s=$ non-stationary at $5 \%$ level of significance.

Finally, the ARNN-ADF test [6] was performed. The bootstrap method with 5000 replications estimated critical values. As shown in Table 6, the ARNN-ADF test confirmed the findings from the ADF test that the tourist arrivals from China, Indonesia, Singapore, Thailand, and India were mean-reverting. This means that post COVID-19 pandemic, international tourist arrivals in Malaysia will recover to pre-pandemic levels. However, the arrivals from Japan, South Korea, Australia, Philippines and Brunei were not mean-reverting, suggesting it might take longer for the international tourists from these countries to return to pre-pandemic levels.

Table 6. Results of the ARNN-ADF Tests.

\begin{tabular}{cccc}
\hline \multicolumn{3}{c}{ Inbound Tourists to Malaysia } \\
\hline Nationality & ADF-ADF Statistics & Bootstrapped (1\% critical value) & Bootstrapped (5\% critical value) \\
\hline Singapore & $-4.98^{*}$ & -7.29 & -4.29 \\
Indonesia & $-5.59^{*}$ & -7.58 & -5.58 \\
China & $-6.57^{*}$ & -4.91 & -4.91 \\
Thailand & $-4.71^{*}$ & -5.99 & -3.99 \\
Brunei & -2.47 & -8.45 & -6.45 \\
India & $-8.70^{*}$ & -6.03 & -5.03 \\
Philippines & -4.72 & -6.90 & -4.90 \\
Japan & -1.22 & -6.20 & -4.20 \\
South Korea & -1.14 & -7.58 & -5.58 \\
Australia & -2.89 & -8.65 & -6.65 \\
\hline
\end{tabular}

Notes: * Indicates significance at the $5 \%$ level

To the best of our knowledge, this is among the first studies to use the ARNN-ADF test to confirm international tourist arrivals in Malaysia. We also used the Unit Root Test to determine if the drop in the inbound tourists visits to Malaysia is permanent or transitory. Using a random walk to simulate the time series of inbound visitors reveals that the series is non-stationary, indicating that visitor arrivals are influenced by long-term changes in the system. It is worth noting that the apparent lack of a unit root (or stationary process) in visit arrivals, as opposed to shocks to visit arrivals, suggests that the shocks to visit arrivals are just transitory [31]. We also confirmed from the ARNN-ADF test that international tourist arrivals in Malaysia would recover post COVID-19 pandemic.

\section{4- Conclusion}

Our findings indicate that the impacts of COVID-19 on inbound tourists in Malaysia are transient. Tourists from five of the major source markets, for example, China, Indonesia, Singapore, Thailand, and India, were expected to return to pre-pandemic levels. As a result of the current situation, certain tourist groups are experiencing both short- and longterm challenges. These findings could be useful for devising targeted marketing campaigns to attract foreign tourists, particularly from Malaysia's major source markets. To summarize, it appears that Malaysia's government authorities should implement a strategy based on the unique impact of the source nation on the long-term number of foreign visitors to address the impact of COVID-19 [32]. 


\section{4-1- Limitations and Future Research}

Although we feel our study has sought to break new ground, we admit that it has certain limitations, yet these point to fruitful paths for future research. First and foremost, we rely on secondary data derived from publicly available information that appears accurate; nevertheless, it would be worthwhile to collect additional primary relevant data to confirm our secondary sources. We may see several different limits to our study. For example, our data on tourists' arrival, hotel occupancy, and other facts are viable options. While the data has been employed frequently in earlier studies, the metrics used in this research are based on subjective evaluations of the data rather than objective analyses. It is critical that future research supports our findings by replicating the work with additional data sets, specifically for studies examining COVID-19's impact in other research investigations. At this moment, we can only locate a limited number of relevant sources. Additionally, the applicability of these results may be limited because of the industryspecific data. The scope of this study may be extended in the future to cover other sectors to provide more robust findings. Future studies should, for example, investigate the role that disease outbreaks have on cross-border tourist numbers in places with the most devastation and how outbreaks affect tourism investment.

\section{5- Policy Implications}

\section{5-1- Governments}

For the tourist sector to revive, it is critical that enabling policies are put in place at the national and local levels. As new regulations for cross-border travel are created, the ASEAN countries may work constructively with businesses and other governments to design these regulations and publicise them well before their implementation. ASEAN governments may provide financial support for recovery by either providing grants or cutting taxes, fees, and levies (The Prihatin Program in Malaysia is a good example.) In addition to direct aid, the Malaysian government offers incentives and help to promote travel and tourism in the nation. To assist Malaysians and foreigners alike to travel more freely, the Malaysian government may increase the promotion of travel destinations and investigate visa facilitation and visa exemptions. While the Malaysian government has implemented comprehensive economic stimulus packages to aid in the crisis, additional solutions that help support tourism businesses and workers must be implemented on a sectoral level and rapidly to promote confidence among travelers. The Malaysian government should also be prepared to stimulate demand once containment measures are lifted. Our second significant lesson from the crisis is the necessity of implementing a comprehensive strategy for tourism policy that integrates disparate regulations and strategies [33]. In this manner, response measures may complement, but still independent of, more significant economic stimulus initiatives (e.g. support measures for tourism enterprises and employees).

\section{5-2- Immigrations}

During pandemics, national governments generally implement rigorous measures to limit inbound and outgoing travel to control the spread of the illness. Among the most stringent measures used thus far have been to quarantine travellers upon arrival and to impose travel limitations. These measures also fulfil the criteria in place today to control the spread of COVID-19. Cross-border travel restrictions affect over 90 percent of the world's population [34]. One hundred fifty-six nations that are destinations for international tourism have put total border closure in place for the first time in June 2020, as reported by the World Tourist Organization [35]. While we are all focused on making the world safe for our families, many believe that an improved policy approach is the way to help people regain confidence. Due to the rapid advance of the COVID-19 virus, countries will need to ease their stringent immigration controls and open their borders to facilitate more efficient travel and tourism.

\section{5-3- Worker and Business Support}

Countries worldwide have developed various cross-sectoral regulations that grant employees greater flexibility and privacy in their schedules to help the travel industry. For many small-scale tourist companies, having legislation that is explicitly aimed at the self-employed is quite relevant. Some countries in which the pandemic's impact on the tourism industry has been damaging have focused on helping the tourism sector by granting tax relief to enterprises, such as postponing VAT payments. The country will also provide other non-financial services, such as educational outreach and advisory services, to help guarantee regulatory compliance [36].

\section{5-4- Lifting Travel Restrictions}

The details of when travel restrictions will be lifted remain unclear at this time. In addition to this, it will be imperative for cooperation between nations to be strengthened to meet healthcare requirements while also allowing the tourist industry to return to a sustainable level of growth in a proper length of time. The World Health Organization is investigating the potential to create travel "corridors" or "bubbles" as the first step in expanding countries tourism opportunities. They have found that countries with a comparable number of COVID-19 cases and good case management processes are planning to use these approaches to facilitate international travel, for example, Singapore and Thailand [37]. 


\section{5-5- Destination Support}

The impact of the pandemic on destinations will fluctuate depending on many factors. Those who are the most dependent on international markets are most likely to be negatively affected, including cities, rural areas, and the natural environment. Other critical factors to consider are the nature of the trip, the effect on tourist flow, and the scope and complexity of the firm's operations [38]. Customized responses offered to destinations will be frequent.

\section{5-6- Restoring Traveller Confidence}

Governments will need to collaborate with the private sector to set new standards in safety, cleanliness, testing, and procedures to assure the traveling public that they are traveling safely. To assure tourists have more health advantages than worries, governments will have to carry out a comparable set of activities [39]. For example, some countries, Malaysia, Singapore, and Thailand have established safe and clean labels to allay tourists' fears. Moreover, they are also researching digital tools like apps for resorts, islands, and beaches, such as Singapore and Thailand, developing an app for a beach, resorts and islands. Nations are striving to increase their domestic and alternative markets and create a positive image of themselves in the global markets in response to the COVID-19 pandemic, e.g. Singapore and Thailand.

\section{6- Declarations}

\section{6-1-Author Contributions}

A.R.A. contributed to the design; P.S. and T.K. implementation of the research; A.R.A. and P.S. analysis of the results; A.R.A. and T.K. writing of the manuscript. The authors have read and agreed to the published version of the manuscript.

\section{6-2-Data Availability Statement}

The data presented in this study are available in insert article.

\section{6-3- Funding}

The authors received no financial support for the research, authorship, and/or publication of this article.

\section{6-4- Conflicts of Interest}

The authors declare that there is no conflict of interests regarding the publication of this manuscript. In addition, the ethical issues, including plagiarism, informed consent, misconduct, data fabrication and/or falsification, double publication and/or submission, and redundancies have been completely observed by the authors.

\section{7- References}

[1] Terzić, Lejla. "How Tourism Destination Competitiveness Contributes To GDP Growth - The Case Of Selected European Economies.” Acta Oeconomica Pragensia 26, no. 3 (September 1, 2018): 24-34. doi:10.18267/j.aop.606.

[2] Balasubramanian, Kandappan, and Neethiahnanthan Ari Ragavan. "What Are the Key Challenges Faced by the Malaysian Hospitality and Tourism Industry in the Context of Industrial Revolution 4.0?" Worldwide Hospitality and Tourism Themes 11, no. 2 (April 8, 2019): 194-203. doi:10.1108/whatt-11-2018-0079.

[3] Garg, Anshul, and Juhi Garg. "Hospitality Interest and Inferred Domains: A Comparative Study among Indian and Malaysian Students." International Journal of Hospitality and Tourism Systems 12, no. 1 (2019): 34.

[4] Sajilan, Sulaiman, Shehnaz Tehseen, and Samuel Adeyinka-Ojo. "A conceptual framework of the impact of entrepreneurial competencies on small and medium enterprises business performance in the Malaysian hospitality and tourism industry." Review of Integrative Business and Economics Research 5, no. 2 (2016): 47.

[5] Fereidouni, Hassan Gholipour, Al-mulali Usama, and Miswan Abdul Hakim Mohammed. "Wealth Effect from Real Estate and Outbound Travel Demand: The Malaysian Case." Current Issues in Tourism 20, no. 1 (February 6, 2014): 68-79. doi:10.1080/13683500.2014.882886.

[6] Yaya, OlaOluwa S., Ahamuefula E. Ogbonna, Fumitaka Furuoka, and Luis A. Gil - Alana. “A New Unit Root Test for Unemployment Hysteresis Based on the Autoregressive Neural Network” Oxford Bulletin of Economics and Statistics 83, no. 4 (March 24, 2021): 960 - 981. doi:10.1111/obes.12422.

[7] Farías-Torbidoni, Estela Inés, and Demir Barić. "The Economic Impact of Tourism on Protected Natural Areas: Examining the Influence of Physical Activity Intensity on Visitors' Spending Levels.” Eco.mont (Journal on Protected Mountain Areas Research) 12, no. 2 (2020): 22-32. doi:10.1553/eco.mont-12-2s22. 
Emerging Science Journal | Vol. 5, Special Issue "COVID-19: Emerging Research", 2021

[8] Comerio, Niccoló, and Fausto Pacicco. "Thank You for Your Staying! An Analysis of the Economic Impact of Tourism in Japanese Prefectures.” Current Issues in Tourism 24, no. 12 (August 4, 2020): 1721-1734. doi:10.1080/13683500.2020.1801604.

[9] Garcia-Muñoz Alhambra, Antonio, Beryl Ter Haar, and Attila Kun. "Harnessing Public Institutions for Labour Law Enforcement." International Organizations Law Review 17, no. 1 (April 18, 2020): 233-260. doi:10.1163/15723747-01701010.

[10] Country Report Malaysia July 2019. In. London: The Economist Intelligence Unit N.A., Incorporated (2019).

[11] Mehdi, Syed Asghar. "Tourism Visitor Export, Income Generation and Employment Capacity: A Comparative Analysis of the Tourism Industries of India, China and Malaysia." IUP Journal of Entrepreneurship Development 16, no. 2 (2019).

[12] Malaysia Tourism Report - Q2 2021. (2021). In (pp. 1). London: Fitch Solutions Group Limited.

[13] Bank, W. Global Financial Development Report 2019/2020: bank regulation and supervision a decade after... the global financial crisis. (2019); World Bank.

[14] Cham, T.-H., Lim, Y.-M., Sia, B.-C., Cheah, J.-H., \& Ting, H. Medical Tourism Destination Image and its Relationship with the Intention to Revisit: A Study of Chinese Medical Tourists in Malaysia. Journal of China tourism research, (2021); 17(2), 163-191. https://doi.org/10.1080/19388160.2020.1734514

[15] Cham, Tat-Huei, Yet-Mee Lim, Bee-Chuan Sia, Jun-Hwa Cheah, and Hiram Ting. "Medical Tourism Destination Image and Its Relationship with the Intention to Revisit: A Study of Chinese Medical Tourists in Malaysia." Journal of China Tourism Research 17, no. 2 (March 15, 2020): 163-191. doi:10.1080/19388160.2020.1734514.

[16] Moosa, Imad A., and Ibrahim N. Khatatbeh. "International Tourist Arrivals as a Determinant of the Severity of Covid-19: International Cross-Sectional Evidence.” Journal of Policy Research in Tourism, Leisure and Events (December 17, 2020): 116. doi:10.1080/19407963.2020.1859519.

[17] Beh, Loo-See, and Woon Leong Lin. "Impact of COVID-19 on ASEAN Tourism Industry." Journal of Asian Public Policy (January 28, 2021): 1-21. doi:10.1080/17516234.2020.1871180.

[18] Yucel, Ali Gokhan. "Are Shocks to Tourist Arrivals Permanent or Transitory? A Comprehensive Analysis on the Top 20 MostVisited Countries." Current Issues in Tourism 24, no. 16 (October 13, 2020): 2294-2311. doi:10.1080/13683500.2020.1828311.

[19] Foo, Lee-Peng, Mui-Yin Chin, Kim-Leng Tan, and Kit-Teng Phuah. "The Impact of COVID-19 on Tourism Industry in Malaysia.” Current Issues in Tourism (June 12, 2020): 1-5. doi:10.1080/13683500.2020.1777951.

[20] Ho, Jie Min, and Joseph Kee Ming Sia. "Embracing an Uncertain Future: COVID-19 and MICE in Malaysia." Local Development \& Society 1, no. 2 (July 2, 2020): 190-204. doi:10.1080/26883597.2020.1818533.

[21] Samdin, Zaiton, Siti Intan Nurdiana Wong Abdullah, Alfred Khaw, and Thanam Subramaniam. "Travel Risk in the Ecotourism Industry amid COVID-19 Pandemic: Ecotourists' Perceptions.” Journal of Ecotourism (June 13, 2021): 1-29. doi:10.1080/14724049.2021.1938089.

[22] Al-Shboul, Mohammad, Sajid Anwar, and Iman Akour. "The Role of Financial and Epidemic Crises on Tourism Loyalty." Journal of Policy Research in Tourism, Leisure and Events (May 17, 2021): 1-34. doi:10.1080/19407963.2021.1928148.

[23] Chua, Bee-Lia, Amr Al-Ansi, Myong Jae Lee, and Heesup Han. "Tourists' Outbound Travel Behavior in the Aftermath of the COVID-19: Role of Corporate Social Responsibility, Response Effort, and Health Prevention.” Journal of Sustainable Tourism 29, no. 6 (November 20, 2020): 879-906. doi:10.1080/09669582.2020.1849236.

[24] Cheung, Yin-Wong, and Kon S. Lai. "Lag Order and Critical Values of the Augmented Dickey-Fuller Test." Journal of Business \& Economic Statistics 13, no. 3 (July 1995): 277-280. doi:10.1080/07350015.1995.10524601.

[25] Lee, Junsoo, and Dante Mossi. “On Improvements of Phillips-Perron Unit Root Tests Using Optimal Bandwidth Estimates.” Applied Economics Letters 3, no. 3 (March 1996): 197-200. doi:10.1080/135048596356681.

[26] Cavaliere, Giuseppe, and A. M. Robert Taylor. “A Note on Testing Covariance Stationarity.” Econometric Reviews 28, no. 4 (January 30, 2009): 364-371. doi:10.1080/07474930802458992.

[27] Andreou, Elena, and Eric Ghysels. "Rolling-Sample Volatility Estimators." Journal of Business \& Economic Statistics 20, no. 3 (July 2002): 363-376. doi:10.1198/073500102288618504.

[28] Chen, Mei-Yuan. "Testing Stationarity against Unit Roots and Structural Changes.” Applied Economics Letters 9 , no. 7 (June 2002): 459-464. doi:10.1080/13504850110091895.

[29] Cavaliere, Giuseppe. “Unit Root Tests under Time-Varying Variances.” Econometric Reviews 23, no. 3 (January 2, 2005): 259292. doi:10.1081/etc-200028215.

[30] Dickey, David A., William R. Bell, and Robert B. Miller. "Unit Roots in Time Series Models: Tests and Implications." The American Statistician 40, no. 1 (February 1986): 12-26. doi:10.1080/00031305.1986.10475349. 
[31] Taylor, A. M. Robert, and Richard J Smith. "Tests of the Seasonal Unit-Root Hypothesis against Heteroscedastic Seasonal Integration.” Journal of Business \& Economic Statistics 19, no. 2 (April 2001): 192-207. doi:10.1198/073500101316970412.

[32] Jamaluddin, Siti Zaharah, Foo Yuen Wah, and Mohammad Abu Taher. "Covid-19: a Preliminary Assessment on the Social Security Framework for an Aged Malaysia." Commonwealth Law Bulletin 47, no. 1 (November 2, 2020): 55-71. doi:10.1080/03050718.2020.1834421.

[33] Pleyers, Geoffrey. "The Pandemic Is a Battlefield. Social Movements in the COVID-19 Lockdown.” Journal of Civil Society 16, no. 4 (August 6, 2020): 295-312. doi:10.1080/17448689.2020.1794398.

[34] Jahari, Siti Aqilah, I-Chieh Michelle Yang, Juliana Angeline French, and Pervaiz Khalid Ahmed. "COVID-19 and Beyond: Understanding Travel Risk Perception as a Process." Tourism Recreation Research (June 23, 2021): 1-16. doi:10.1080/02508281.2021.1937450.

[35] Kuščer, Kir, Sarah Eichelberger, and Mike Peters. "Tourism Organizations' Responses to the COVID-19 Pandemic: An Investigation of the Lockdown Period.” Current Issues in Tourism (May 27, 2021): 1-14. doi:10.1080/13683500.2021.1928010.

[36] Li, Zhiyong, Qingxue Zhao, Tingting Huo, Yuhong Shao, and Zhongyi Hu. "COVID-19: Management Focus of Reopened Tourist Destinations." Current Issues in Tourism (December 25, 2020): 1-7. doi:10.1080/13683500.2020.1863926.

[37] Rather, Raouf Ahmad. "Monitoring the Impacts of Tourism-Based Social Media, Risk Perception and Fear on Tourist's Attitude and Revisiting Behaviour in the Wake of COVID-19 Pandemic." Current Issues in Tourism (February 10, 2021): 1-9. doi:10.1080/13683500.2021.1884666.

[38] Ateljevic, Irena. "Transforming the (tourism) World for Good and (re)generating the Potential 'new Normal." Tourism Geographies 22, no. 3 (May 2, 2020): 467-475. doi:10.1080/14616688.2020.1759134.

[39] Lapointe, Dominic. "Reconnecting Tourism after COVID-19: The Paradox of Alterity in Tourism Areas.” Tourism Geographies 22, no. 3 (May 5, 2020): 633-638. doi:10.1080/14616688.2020.1762115. 